
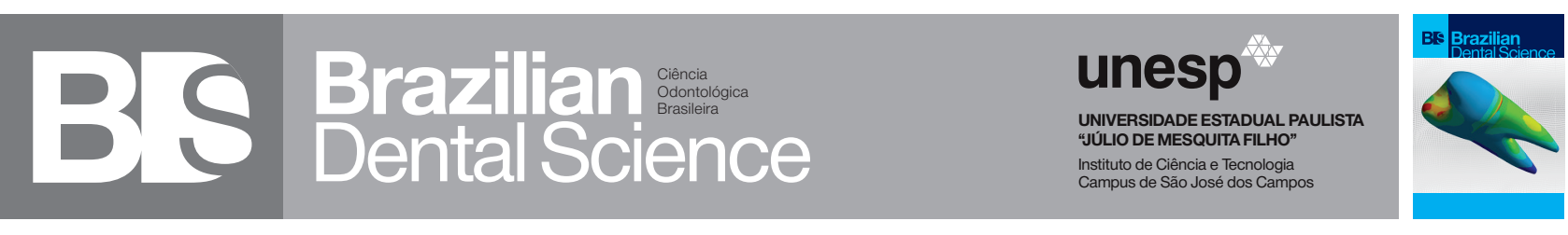

\title{
How to improve the early diagnosis of oral cancer?
}

\author{
Como melhorar o diagnóstico precoce do câncer bucal?
}

Celso Muller BANDEIRA ${ }^{1}$, Adriana Ávila de ALMEIDA ${ }^{1}$, Celina Faig Lima CARTA ${ }^{2}$, Janete Dias ALMEIDA ${ }^{1}$, Estela KAMINAGAKURA ${ }^{1}$

1 - São Paulo State University (Unesp) - Institute of Science and Technology - São José dos Campos - Department of Biosciences and Oral Diagnosis - SP - Brazil.

2 - University Braz Cubas - Mogi das Cruzes - SP - Brazil.

\begin{abstract}
Objective: Oral squamous cell carcinoma (OSCC) is one of the most common malignant neoplasms, with 300,000 new cases annually diagnosed in the world. Although it appears in the fifth position among men in Brazil, late diagnosis continues to be a leading cause of poor prognosis. We reviewed the literature to evaluate factors that contribute to diagnostic delay in oral cancer considering aspects related to the patient, health team and public health system. Material and Methods: The Medline (PubMed), Scopus, Web of Science and Embase databases were searched in the last 5 years using the following MeSH descriptors: carcinoma, squamous cell; mouth neoplasms; delayed diagnosis. The articles should contain in their objectives factors contributing to the delayed diagnosis of OSCC related to the patient, healthcare professionals and public health system in general. Results: One hundred twenty articles were retrieved and 27 on the delayed diagnosis of oral cancer were eligible. Conclusion: The literature showed that the delay in the diagnosis and treatment of patients with oral cancer could be minimized by providing health information, particularly about risk factors, by improving the training and retraining of physicians and dentists and by improving access to the health system. The communication technologies such as telemedicine, can play a key role in the early diagnosis of oral cancer.
\end{abstract}

\section{KEYWORDS}

Carcinoma; Squamous Cell; Mouth Neoplasms; Delayed Diagnosis.

\section{RESUMO}

Objetivo: o carcinoma de células escamosas de cavidade bucal (CCECB) é uma das neoplasias malignas mais comuns, com cerca de 300 mil novos casos diagnosticados anualmente no mundo. Embora esteja na quinta posição entre os mais frequentes em homens no Brasil, o diagnóstico tardio continua a ser a principal causa de mau prognóstico. Revisamos a literatura para avaliar fatores que possam contribuir para o atraso de diagnóstico no câncer bucal considerando aspectos relacionados ao paciente, equipe de saúde e o Sistema de Saúde Pública. Material e Métodos: Foram pesquisados os bancos de dados Medline (PubMed), Scopus, Web of Science e Embase nos últimos 5 anos utilizando os seguintes descritores MeSH: carcinoma de células escamosas, neoplasias de boca e atraso diagnóstico. Os artigos deveriam conter em seus objetivos fatores que possam ter contribuído para o diagnóstico tardio do CCECB relacionado ao paciente, aos profissionais de saúde e ao Sistema de Saúde Pública em geral. Resultados: Cento e vinte artigos foram recuperados, sendo elegíveis, vinte e sete relacionados ao diagnóstico tardio de câncer bucal. Conclusão: a literatura mostrou que o atraso no diagnóstico e tratamento de pacientes com câncer bucal poderia ser minimizado, fornecendo informações sobre saúde, particularmente sobre fatores de risco a população, melhorando o treinamento e reciclagem de médicos e dentistas e melhorando o acesso ao sistema de saúde. As tecnologias de comunicação, dentre elas a telemedicina, pode desempenhar um papel fundamental no diagnóstico precoce de câncer bucal.

\section{PALAVRAS-CHAVE}

Carcinoma de células escamosas; Neoplasias de boca; Atraso diagnóstico. 


\section{INTRODUCTION}

$\mathrm{O}$ ral cancer is one of the most common malignant neoplasms in the world, with the diagnosis of about 300.000 new cases every year. In Brazil, oral cancer is the fifth most common cancer among men, with about 7,2 new cases/100.000 inhabitants [1].

Factors such as smoking and alcohol consumption have been associated with the occurrence of oral cancer [2]. Furthermore, human papillomavirus (HPV) has been well established as an etiological factor of oropharyngeal tumors, but its role in the etiology of oral squamous cell carcinoma (OSCC) is controversial. However, a Brazilian study reported, a prevalence of high risk DNA of HPV in approximately $20 \%$ of cases, being more frequent in young adults [3]

The main prognostic factors of oral cancer are the size and location of the tumor, presence of regional or distant metastases according to the Tumor Node Metastasis Classification (TMN) [4], degree of local invasion, involvement of deep structures, tumor-free surgical margins, and capsular extravasation of the lymph node, as well as habits [5-7]. However, the conventional TNM has been insufficient to predict the response to treatment.

Despite numerous studies with tumor markers, in general, there are no specific biomarkers for oral cancer [8]. Therefore, the most important and decisive factor is an early diagnosis. The tumor often passes unnoticed by the patient and healthcare professionals, a fact resulting in delayed treatment and compromising patient cure [9].

At present, the early diagnosis is the most important factor for a favorable prognosis of oral malignant tumors. The objective of this literature review was to list and discuss the main factors associated with delayed diagnosis and treatment in patients with oral cancer.

\section{MATERIAL AND METHODS}

The Web of Science, Scopus, Embase, and PubMed databases were searched using the following MeSH descriptors: carcinoma, squamous cell; mouth neoplasms; delayed diagnosis. Criteria for inclusion were articles published in English, over the last 5 years.

\section{RESULTS}

A total of 120 articles were retrieved, including 10 from the National Library of Medicine (PubMed), 19 from the Web of Science, 28 from Scopus, and 63 from Embase (Figure 1)

Seventy-four articles that did not mention or were not directly related to the topic (diagnostic delay caused by the patient, diagnostic delay caused by the health team prior to the specialist, and delay after visit to the specialist and before the beginning of cancer treatment) were excluded. Forty-eight articles retrieved from Embase were excluded, 13 from Scopus, 10 from the Web of Science, and 3 from PubMed (Figure 2).

Nineteen of the 46 selected articles were also excluded due to duplication in the databases and 27 articles were thus eligible (Figure 3).

Many factors contribute to diagnostic delay in oral cancer. The main factors that contributed to the diagnosis delay identified in the articles reviewed were:

1. Lack of knowledge of the disease: early symptoms unspecific, low incidence compared to other malignancies tumour, and fears of the diagnosis were the main factors related to patients suffering. In addition, self-medication and illiteracy were considered important factors as responsible for patient-related delays [10-14].

2. Behavior of tumors: the biological behavior of tumors can differ from one individual to another among them, the degree of tumor differentiation, their location, and own definition of an initial, small, and even early tumor has been questioned [15-17]. 
3. The level of knowledge the professionals directly involved in the diagnosis as physicians and dentists have shown variations [17-19].

When analyzing factors involved on treatment delay, perhaps one of the most important aspect is the delay caused by the patient, followed by the health professional, other people not properly qualifyed and finally, the health system itself. In a survey evaluating the reasons for the delay diagnosis in India the authors observed that $52 \%$ of cases it was caused by the patient, while in $34 \%$ and $14 \%$ it was due to health professionals or alternative tretments and health system respectively [20]. Another study, $56 \%$ of the patients sought medical care over 4 months of disease progression [21]. However, it can be quite variable among different countries and population. Moreover, these factors usually overlap, making it difficult to analyze them more accurately.

\section{Database}

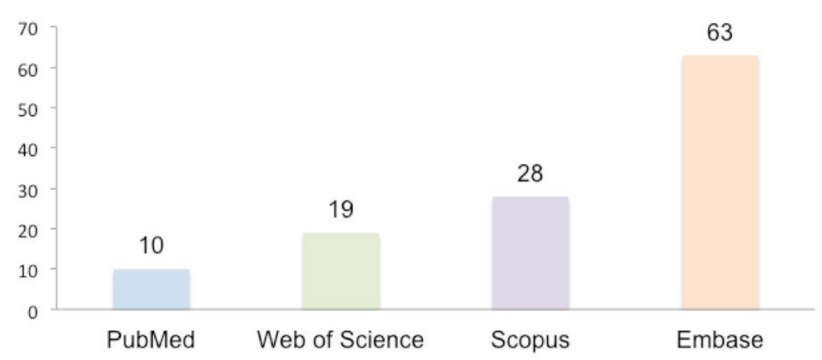

Figure 1- Articles according to database

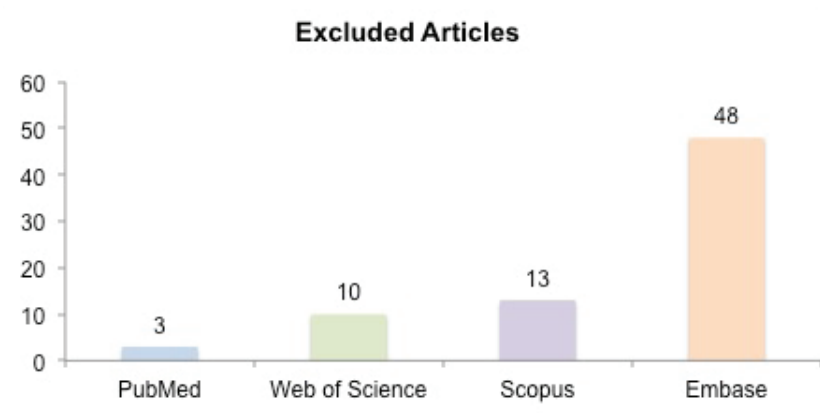

Figure 2 - Excluded articles

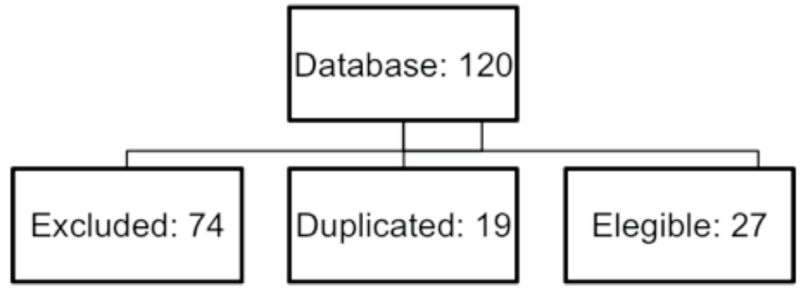

Figure 3 - Flow chart of the results

\section{DISCUSSION}

\section{Patient-related factors}

One of the main factors contributing to diagnostic delay in oral cancer is probably the lack of knowledge of the general population about the disease. In countries such as Saudi Arabia and India, a large part of the population is unaware of the signs and symptoms of the disease $[10,11]$. The disease is often neglected in cases in which symptoms are absent [20]. Oral squamous Cell Carcinoma (OSCC) accounts for 2 to $5 \%$ of all cancer cases in different world populations [1]. Sociocultural factors are also important for the maintenance of smoking and drinking habits. Different peoples and nations exhibit different behaviors in terms of exposure, social acceptance and understanding of the habit.

Once the tumor is installed and because of the lack of knowledge of the problem, many individuals seek treatment in the community with pharmacists, healers and faith healers [20]. In addition to the self-indication of popular teas and herbs prior to a medical visit it was an important factor delay diagnosis [13].

Illiteracy, or primary literacy, is also a factor causing delay in diagnosis, especially if these individuals have visited general practitioners 3 or 4 times and did not receive the diagnosis of oral cancer, somehow accepting the erroneous guidance of the professional [14]. In this situation, although the diagnostic delay can be attributed to the patient, we must also consider the responsibility of the poorly skilled professional in establishing the diagnosis of oral cancer. Although illiteracy has been considered 
as a factor of diagnostic delay, some authors have not considered this as an important factor. In a Brazilian study, illiteracy was not observed [22].

In a recent study conducted among oral cancer patients in Pakistan the authors observed that about $40 \%$ of cases had graduation and post graduation, 55\% had secondary education, and $5 \%$ had primary education. In this stratified analysis, there was no significance between the degree of schooling and the incidence of cancer [21].

Young patients usually underestimate the severity of disease and, when signs and symptoms appear, tend to wait a longer period for spontaneous resolution of the clinical symptoms. The same generally does not apply to older patients. Factors such as fear, denial, neglect and medical mistrust can be observed [12]. Another factor is the difficulty encountered by the patient to measure the period of diagnostic delay since the symptoms are based on the perception of the problem, which can be highly subjective and influenced by personal and cultural factors [23].

In a review on oral cancer and delayed diagnosis, the authors concluded that patient delay is the main factor contributing to the diagnostic delay in oral cancer [9]. However, in most developing countries where oral cancer is endemic, disruption of the health system seems to be a primary factor. It is not sufficient to hold the population accountable if the public health system is deficient in these countries.

\section{Tumor-related factors}

The biological behavior of tumors can differ from one individual to another. Slow-growing well-differentiated tumors found in less visible areas are more likely to be diagnosed late. In contrast, poorly differentiated, rapidly growing tumors generally are easily perceived by the patient and are diagnosed earlier [15].

Another factor to be considered is that in some cases the biological or tumor and patient characteristics such as immunosuppression are added and no delay occurs [24]. In this respect, further studies investigating markers of tumor growth in premalignant lesions would be important, however these tests are expensive and usually in no standardization for population screening exists.

The location of the tumor can also contribute to diagnostic delay. Although easily visible, lesions located in the gingiva are diagnosed in late stages not because of the time of diagnosis itself, but because of the rapid invasion of deeper tissues [16]. However, according to some authors, OSCC affecting the gingiva usually does not have a more aggressive behavior since this tumor is generally exophytic and its invasion potential is limited [25].

Another issue is to define the early diagnosis of OSSC. A tumor that is at the beginning of carcinogenesis? A tumor that was diagnosed at a relatively small size? A tumor that was detected rapidly after the onset of symptoms? The definition of an initial, small, early tumor has been questioned. A lesion measuring $1.0 \mathrm{~cm}^{3}$ has already undergone about 10 billion cell divisions [17].

\section{Health team-related factors}

Different factors can be considered when the delayed diagnosis caused by healthcare professionals is analysed. Factors such as academic background, professional experience and reutilization of knowledge can influence diagnostic capacity. Since OSCC is somehow a "rare" tumor, the difficulty of healthcare professionals in establishing the diagnosis is not surprising, particularly in young patients, with diagnostic delays of up to 5 weeks [17].

Studies analysing the level of knowledge of physicians and dentists have shown variations when the participants were asked about risk factors and characteristics of the lesions. Few participants knew that erythroplakia is associated with oral cancer and were unaware of its most common sites [18]. Furthermore, factors 
unrelated to oral cancer were cited erroneously by the professionals as risk factors, such as poor oral hygiene and ill-fitting dentures [18]. Only just over $10 \%$ of the participants reported to have learned about oral cancer during their undergraduate course, in contrast to a Canadian study in which about $50 \%$ of the respondents had adequate training during the undergraduate course. However, although the percentage of training was higher in the Canadian study, only $43 \%$ of the participants identified erythroplakia and leukoplakia lesions as conditions associated with oral cancer [26].

In daily practice, it is common cancer patients seek medical and dental care and undergo some kind of misdiagnosis of periodontitis, or pulp infection and receive drug treatment, or dental intervention, and have their diagnosis of cancer neglected [19]. As a result of the persistence of symptoms after these procedures, the patients seek a specialized service. The effect of this diagnostic delay on prognosis is controversial and was not considered an important factor in a study conducted in Japan [19].

If we take into consideration which professional should make the early diagnosis, the dentist or physician, the access and opportunity of an early diagnosis are even more limited. A priori any health professional should be able to make diagnosis of oral cancer. A study conducted in Canada showed that general practitioners more frequently diagnosed oral cancer, but in advanced stages [26]. However, in a Brazilian study, only $3 \%$ of patients with oral and oropharyngeal cancer were examined by a specialist in head and neck surgery in the first month after the onset of symptoms [27].

Today, contact centers with specialized health professionals have enabled the contact web and exchange of experiences between different centers in different areas of knowledge. Thinking about it, we believe it is the role of colleges and specialty associations to promote this method of communication and exchange of experience between academic professionals and other professionals in their primary care clinics. Several areas of medicine and dentistry have already observed this mode of communication and have begun to discuss the issue as the best results $[28,29]$.

\section{Public health system-related factors}

Most patients with oral cancer are seen in an advanced stage, a fact compromising their prognosis. In a study conducted in Iran, the mean diagnostic delay was 7.2 months and two-thirds of this delay were attributed to the patient and professional [30]. These findings highlight the importance of encouraging general practitioners and dentists to actively search for lesions during routine clinical practice.

There seems to be sufficient evidence for a relationship between screening of the general population for early visible lesions and a reduction in mortality due to OSCC. However, the value of early detection programs for groups with risk habits is questionable because of the potential to produce a considerable number of false-positive cases [31]. Furthermore, the population that participates in such campaigns does usually not belong to a risk group [32]. For this reason, some countries discourage their health services to perform oral cancer prevention campaigns because of their low cost-effectiveness [26]. Explanatory leaflets containing information about the disease are usually not effective considering the large number of illiterate individuals affected. Studies evaluating this type of approach generally yield inconclusive results because of the large number of variables [33].

Each community has its own profile, i.e., individual characteristics of the population, organization of the health system, vocational training and, finally, all interrelations between them. Furthermore, the delay in diagnosis should not be viewed as an independent time factor. In daily clinical practice, these periods of diagnostic delays overlap and each delay factor has its share of responsibility [34]. 
Nowadays the concept of telemedicine has been used to describe a set of communication possibilities aimed at an exchange of information between health professionals, patients, specialized centers, providing an exchange of experiences and direct contact between geographically distant people. A specialty such as Urology has discussed this form of communication [29]. Thinking about it, perhaps we could start a discussion on the important modes of communication including mobile phone applications for the exchange of information between different locations in order to provide a new tool in the early diagnosis of oral cancer, reducing time and particularly cost in the treatment of these patients.

If this measurement is difficult, greater emphasis may be placed on the treatment of habits associated with cancer such as smoking and alcohol consumption whose abuse is defined as disease by the World Health Organization, but which are not recognized as important factors for the prevention of OSCC.

\section{CONCLUSION}

Studies in the literature show that the delay in the diagnosis and treatment of patients with oral cancer could be minimized by providing information to the population, particularly about risk factors, by improving the training and retraining of physicians and dentists, by improving access of these patients to the health system. The use of communication technologies such as telemedicine can play a key role in the early diagnosis of oral cancer.

\section{REFERENCES}

1. International Agency for Research on Cancer (2014). Globocan 2012: estimated cancer incidence, mortality and prevalence worldwide in 2012: population fact sheets. Retrieved from http:// globocan.iarc.fr/Pages/fact sheets population.aspx. Acessed on 16 Jan 2017

2. Curado MP, Hashibe M. Recent changes in the epidemiology of head and neck cancer. Curr Opin Oncol. 2009 May;21(3):194-200. doi: 10.1097/CCO.0b013e32832a68ca.
3. Kaminagakura E, Villa LL, Andreoli MA, Sobrinho JS, Vartanian JG, Soares FA, et al. High-risk human papillomavirus in oral squamous cell carcinoma of young patients. Int J Cancer. $2012 \mathrm{Apr}$ 15;130(8):1726-32. doi: 10.1002/ijc.26185.

4. Website of the Union for International Cancer Control TNM (2016). Retrieved from: http://www.uicc.org/resources/tnm. Acessed on 16 Jan 2017

5. Almangush A, Bello I0, Coletta RD, Makitie AA, Makinen LK, Kauppila JH, et al. For early-stage oral tongue cancer, depth of invasion and worst pattern of invasion are the strongest pathological predictors for locoregional recurrence and mortality. Virchows Arch. 2015 Jul;467(1):39-46. doi: 10.1007/s00428-0151758-z. Epub 2015 Apr 3.

6. More Y, D'Cruz AK. Oral cancer: Review of current management strategies. Natl Med J India. 2013 May-Jun;26(3):152-8.

7. World Health Organization. World Cancer Report. 2014. Lyon: IARC 2014.

8. Rivera C. Essentials of oral cancer. Int J Clin Exp Pathol. 2015 Sep 1;8(9):11884-94. eCollection 2015.

9. Stefanuto P, Doucet JC, Robertson C. Delays in treatment of oral cancer: a review of the current literature. Oral Surg Oral Med Oral Pathol Oral Radiol. 2014 Apr;117(4):424-9. doi: 10.1016/j. 0000.2013.12.407

10. Al-Maweri SA, Tarakji B, Alsalhani AB, Al-Shamiri HM, Alaizari NA, Altamimi MA, et al. Oral cancer awareness of the general public in saudi arabia. Asian Pac J Cancer Prev. 2015;16(8):3377-81.

11. Piddennavar R, Krishnappa P. Preparation and evaluation of information leaflet for tobacco users. J Educ Health Promot. 2015 Mar 26;4:19. doi: 10.4103/2277-9531.154039.

12. Van der Waal I, de Bree R, Brakenhoff R, Coebergh JW. Early diagnosis in primary oral cancer: is it possible? Med Oral Patol Oral Cir Bucal. 2011 May 1;16(3):e300-5.

13. Panzarella V, Pizzo G, Calvino F, Compilato D, Colella G, Campisi G. Diagnostic delay in oral squamous cell carcinoma: the role of cognitive and psychological variables. Int J Oral Sci. 2014 Mar;6(1):39-45. doi: 10.1038/ijos.2013.88.

14. Esmaelbeigi F, Hadji M, Harirchi I, Omranipour R, vand Rajabpour M, Zendehdel K. Factors affecting professional delay in diagnosis and treatment of oral cancer in Iran. Arch Iran Med. 2014 Apr;17(4):2537. doi: 014174/AIM.007

15. Scott SE, Grunfeld EA, McGurk M. Patient's delay in oral cancer: A systematic review. Community Dent Oral Epidemiol. 2006 0ct;34(5):337-43.

16. Carvalho AL, Pintos J, Schlecht NF, Oliveira B V, Fava AS, Curado MP et al. Predictive factors for diagnosis of advanced-stage squamous cell carcinoma of the head and neck. Arch Otolaryngol Head Neck Surg. 2002 Mar;128(3):313-8.

17. Ding Y, Ma L, Shi L, Feng J, Liu W, Zhou Z. Papillary squamous cell carcinoma of the oral mucosa: a clinicopathologic and immunohistochemical study of 12 cases and literature review. Ann Diagn Pathol. 2013 Feb;17(1):18-21. doi: 10.1016/j. anndiagpath.2012.04.005.

18. Alami AY, El Sabbagh RF, Hamdan A. Knowledge of oral cancer among recently graduated medical and dental professionals in Amman, Jordan. J Dent Educ. 2013 0ct;77(10):1356-64. 
19. Yamagata K, Ito H, Onizawa K, Yamatoji M, Yanagawa T, Bukawa H. Prognosis for gingival carcinomas with a delayed diagnosis after dental extraction. J Oral Maxillofac Surg. 2013 Dec;71(12):2189-94. doi: 10.1016/j.joms.2013.05.008.

20. Joshi P, Nair S, Chaturvedi P, Nair D, Agarwal JP, D'Cruz AK. Delay in seeking specialized care for oral cancers: experience from a tertiary cancer center. Indian J Cancer. 2014 Apr-Jun;51(2):95-7. doi: 10.4103/0019-509X.137934.

21. Naseer, R, Naz, I, Mahmood, MK. Frequency of delayed diagnosis of oral squamous cell carcinoma in Pakistan. Asian Pac J Cancer Prev. 2016 Nov 1;17(11):5037-5040.

22. Felippu AW, Freire EC, Silva Rde A, Guimarães AV, Dedivitis RA. Impact of delay in the diagnosis and treatment of head and neck cancer. Braz J Otorhinolaryngol. 2016 Mar-Apr;82(2):140-3. doi: 10.1016/j.bjorl.2015.10.009.

23. Scott SE, Grunfeld EA, McGurk M. The idiosyncratic relationship between diagnostic delay and stage of oral squamous cell carcinoma. Oral Oncol. 2005 Apr;41(4):396-403.

24. Seoane-Romero JM, Vázquez-Mahía I, Seoane J, Varela-Centelles P, Tomás I, López-Cedrún JL. Factors related to late stage diagnosis of oral squamous cell carcinoma. Med Oral Patol Oral Cir Bucal. 2012 Jan 1;17(1):e35-40.

25. Seoane J, Varela-Centelles PI, Walsh TF, Lopez-Cedrun JL, Vazquez I. Gingival squamous cell carcinoma: diagnostic delay or rapid invasion? J Periodontol 2006;77(7):1229-33. doi: 10.1902/ jop.2006.050408

26. Groome PA, Rohland SL, Hall SF, Irish J, Mackillop WJ, O'Sullivan B. A population-based study of factors associated with early versus late stage oral cavity cancer diagnoses. Oral Oncol 2011;47(7):642-7.
27. Kowalski LP, Franco EL, Torloni H, Fava AS, de Andrade Sobrinho J, Ramos G, et al. Lateness of diagnosis of oral and oropharyngeal carcinoma: factors related to the tumour, the patient and health professionals. Eur J Cancer B Oral Oncol 1994;30B(3):167-73.

28. Birur PN, Sunny SP, Jena S, Kandasarma U, Raghavan S, Ramaswamy B, et al. Mobile health application for remote ora cancer surveillance. J Am Dent Assoc 2015;146(12):886-94.

29. Ellimoottil C, Skolarus T, Gettman M, Boxer R, Kutikov A, Lee BR, et al. Telemedicine in Urology: State of the Art. Urology. 2016 Aug;94:10-6. doi: 10.1016/j.urology.2016.02.061.

30. Sargeran K, Murtomaa H, Safavi SM, Teronen 0. Delayed diagnosis of oral cancer in Iran: challenge for prevention. Oral Heal Prev Dent 2009;7(1):69-76.

31. Brocklehurst P, Kujan 0, 0'Malley LA, Ogden G, Shepherd S, Glenny AM. Screening programmes for the early detection and prevention of oral cancer. Cochrane Database Syst Rev. 2013;19;(11):CD004150. doi: 10.1002/14651858.CD004150.pub4.

32. Nemoto RP, Victorino AA, Pessoa GB, da Cunha LL, da Silva JA, Kanda JL, et al. Oral cancer preventive campaigns: are we reaching the real target? Braz J Otorhinolaryngol. 2015 Jan-Feb;81(1):44-9. doi: 10.1016/j.bjorl.2014.03.002

33. Noonan B. Understanding the reasons why patients delay seeking treatment for oral cancer symptoms from a primary health care professional: an integrative literature review. Eur J Oncol Nurs 2014;18(1):118-24. doi: 10.1016/j.ejon.2013.07.005

34. Christophe V, Leroy T, Seillier M, Duthilleul C, Julieron M, Clisant $S$, et al. Determinants of patient delay in doctor consultation in head and neck cancers (Protocol DEREDIA). BMJ Open. $2014 \mathrm{Jul}$ 25;4(7):e005286. doi: 10.1136/bmjopen-2014-005286.

\section{Estela Kaminagakura}

(Corresponding address)

São Paulo State University (Unesp) - Institute of Science and Technology - São José dos Campos - Department of Biosciences and Oral Diagnosis - SP - Brazil.

Av. Francisco José Longo, 777 - Bairro São Dimas, CEP: 12245-000 São José dos Campos, São Paulo, Brazil. Fax number: (+551239479010); Telephone number: $(+551239479000)$

Date submitted: 2017 May 30 Accept submission: 2017 Dec 04 